\title{
PENYIMPANGAN DALAM PENERBITAN SERTIPIKAT HAK ATAS TANAH
}

\author{
Urip Santoso \\ Fakultas Hukum Universitas Airlangga Surabaya \\ e-mail: urip_sts@yahoo.com
}

\begin{abstract}
ABSTRAK
Salahsatu kegiatan dalam hal pendaftaran tanah adalah diterbitkannya sertipikat hak atas tanah sebagai tanda bukti hak oleh Kantor Pertanahan. Dengan diterbitkan sertipikat ini, nantinya akan dengan mudah dapat dibuktikan siapa pemegang haknya. Dengan diterbitkan sertipikat, akan terwujud jaminan kepastian hukum dan perlindungan hukum bagi pemegang haknya. Pada kenyataan dalam praktiknya, terjadi tindakan penyimpangan dalam penerbitan sertipikat, yang mana hal ini terjadi dalam beberapa bentuk, yaitu diterbitkannya sertipikat palsu, sertipikat asli namun ternyata palsu, sertipikat ganda, sertipikat tumpang tindih, dan juga sertipikat fiktif.

Kata Kunci: penyimpangan, sertipikat, hak atas tanah.

ABSTRACT

One thing that is required in land registration activity is the issuance of the certificate of land rights by the land office, which is used commonly as an evidence. By the issuance of this certificate, it will ease the process of proofing the ownership of the related land. The issuance of this certificate will definetely realize the legal certainty and legal protection to the owner. In fact, there was an act of irregularities in the issuance of certificates, which occured in several forms, such as the issuance of fake certificates, original certificates but apparently false, multiple certificates, certificates of overlap, as well as fictitious certificates.
\end{abstract}

Keywords: deviation, certificates, land rights.

\section{PENDAHULUAN}

Hukum Tanah yang berlaku sebelum Indonesia merdeka tanggal 17 Agustus 1945, Hukum Tanah Kolonial ditetapkan dan diberlakukan oleh Pemerintah Hindia-Belanda tepatnya di wilayah Hindia-Belanda (Indonesia) berdasarkan Burgerlijk Wetboek (yang selanjutnya disebut BW), Agrarsche Wet Stb. 1870 No. 55, dan Agrarische Besluit Stb. 1870 No. 118.

Pada masa penjajahan Belanda di Indonesia, di Indonesia terdapat 3 (tiga) macam Hukum Tanah, yaitu: 1. Hukum Tanah Barat; 2. Hukum Tanah Adat; 3. Hukum Tanah Daerah Swapraja

Hukum Tanah Kolonial mempunyai 3 (tiga) ciri, antara lain: 1. Hukum Tanah disusun berdasarkan tujuan dan sendi-sendi dari pemerintahan jajahan dan sebagian dipengaruhi olehnya; 2. Hukum Tanah mempunyai sifat dualisme hukum, yaitu pada saat yang sama berlaku Hukum Tanah Barat dan Hukum Tanah Adat; 3. Bagi rakyat Indonesia asli, Hukum Tanah Kolonial tidak mempunyai jaminan kepastian hukum.

Pada masa berlakunya Hukum Tanah Kolonial, hanya tanah-tanah yang tunduk pada Hukum Barat, diantaranya tanah-tanah yang dimiliki oleh orang- orang dari Golongan Eropa, yang mana berupa Hak Eigendom, Hak Opstal, Hak Erfpacht, dan Hak van Gebruik yang didaftar dan diterbitkan tanda bukti hak berupa akta (sertipikat), sedangkan tanah-tanah yang tunduk pada Hukum Adat, yaitu tanah-tanah yang dimiliki oleh orang-orang dari Golongan Bumi Putera tidak didaftar dan tidaklah diterbitkan tanda bukti hak yang berupa akta (sertipikat). Tanah-tanah yang tunduk pada Hukum Adat diterbitkan tanda bukti pembayaran pajak atas tanah berupa Petuk Pajak Bumi atau Landrente, Girik, Kekitir, Pipil, Verponding Indonesia.

Hukum Tanah Nasional berlaku sejak berlakunya Undang-Undang No. 5 Tahun 1960 tentang Peraturan Dasar Pokok-Pokok Agraria, atau yang lebih dikenal dengan sebutan/nama Undang-Undang Pokok Agraria (yang selanjutnya disebut UUPA), pada tanggal 24 September 1960. UUPA secara tegas menetapkan tidak berlaku Buku II BW sepanjang mengatur bumi, air, dan kekayaan alam yang terkandung di dalamnya, kecuali ketentuan mengenai Hypotheek, Agrarische Wet Stb. 1870 No. 55, dan Agrarische Besluit Stb. 1870 No. 118. 
UUPA merupakan pelaksanaan ketentuan Pasal 33 ayat 3 Undang-Undang Dasar 1945 (yang selanjutnya disebut UUD 45). Hal ini disebutkan dalam Pasal 2 ayat 1 UUPA, bahwa atas dasar ketentuan dalam Pasal 33 ayat 3 Undang-Undang Dasar dan hal-hal sebagai yang dimaksud dalam Pasal 1, bumi, air, dan ruang angkasa, termasuk kekayaan alam yang terkandung di dalamnya itu pada tingkatan tertinggi dikuasai oleh Negara, sebagai organisasi kekuasaan seluruh rakyat. Berdasarkan ketentuan ini, negara sebagai organisasi kekuasaan seluruh rakyat hanyalah berkedudukan menguasai bumi, air, dan ruang angkasa, termasuk kekayaan alam yang terkandung di dalamnya.

Tujuan diundangkan UUPA disebutkan dalam Penjelasan Umumnya UUPA, antara lain: Pertama, meletakkan dasar-dasar bagi penyusunan Hukum Agraria Nasional, yang akan merupakan alat untuk membawakan kemakmuran, kebahagiaan, dan juga keadilan bagi negara dan rakyat, terutama rakyat tani dalam rangka masyarakat yang adil dan makmur; Kedua, meletakkan dasar-dasar untuk mengadakan kesatuan dan juga kesederhanaan di dalam Hukum Pertanahan; Ketiga, meletakkan dasar-dasar untuk memberikan kepastian hukum mengenai hak-hak atas tanah bagi rakyat seluruhnya.

Untuk mewujudkan tujuan memberikan jaminan kepastian hukum dilakukan melalui 2 (dua) upaya, antara lain: 1. membuat peraturan pelaksanaan yang diperintahkan oleh UUPA, yang isinya jelas dan tidak bertentangan dengan jiwa UUPA; 2. mengadakan pendaftaran tanah yang mana bersifat rechts cadaster bukan fiscal cadaster.

Dalam hal melaksanakan tujuannya memberikan jaminan kepastian hukum, UUPA telah menetapkan kegiatan pendaftaran tanah yang bersifat memberikan jaminan kepastian hukum atau rechts cadaster. UUPA menetapkan bahwa yang berkewajiban melaksanakan pendaftaran tanah adalah pemerintah dan pemegang hak atas tanah. Ketentuan yang menetapkan bahwa pemerintah berkewajiban mengadakan pendaftaran tanah adalah Pasal 19 ayat 1 UUPA, yaitu untuk menjamin kepastian hukum oleh pihak pemerintah maka diadakan pendaftaran tanah di seluruh wilayah Republik Indonesia menurut ketentuan-ketentuan yang diatur dengan Peraturan Pemerintah. Ketentuan yang menetapkan bahwa pemegang hak atas tanah berkewajiban mengadakan pendaftaran tanah diatur dalam Pasal 23 UUPA untuk pemilik tanah, Pasal 32 UUPA untuk pemegang Hak Guna Usaha (HGU), Pasal 38 UUPA untuk pemegang Hak Guna Bangunan (HGB), dan Pasal 41 UUPA untuk pemegang Hak Pakai (HP).
Ketentuan lebih lanjut pendaftaran tanah menurut Pasal 19 ayat 1 UUPA diatur Peraturan Pemerintah. Peraturan Pemerintah yang mana telah diperintahkan disini semula adalah Peraturan Pemerintah No. 10 Tahun 1961 tentang Pendaftaran Tanah. Kemudian, Peraturan Pemerintah No. 10 Tahun 1961 dinyatakan tidak berlaku lagi oleh Peraturan Pemerintah No. 24 Tahun 1997 tentang Pendaftaran Tanah. Peraturan Pemerintah No. 24 Tahun 1997 dilaksanakan oleh Peraturan Menteri Negara Agraria/Kepala Badan Pertanahan Nasional No. 3 Tahun 1997 mengenai Ketentuan Pelaksanaan Peraturan Pemerintah No. 24 Tahun 1997 tentang Pendaftaran Tanah.

Pasal 19 ayat 2 UUPA mengatur bahwa kegiatan pendaftaran tanah yang diadakan oleh pemerintah yaitu pengukuran, perpetaan, dan juga pembukuan tanah; pendaftaran hak-hak atas tanah dan peralihan hak-hak tersebut; dan pemberian surat-surat tanda bukti hak yang berlaku sebagai alat pembuktian yang kuat.

Salah satu kegiatan dalam hal pendaftaran tanah adalah pemberian surat-surat tanda bukti hak yang berlaku sebagai alat bukti yang kuat. Surat tanda bukti hak tersebut dikenal dengan sebutan sertipikat. Secara prosedural, sertipikat diterbitkan oleh Kantor Pertanahan Kabupaten atau Kota. Sertipikat memuat data fisik dan data yuridis atas tanah yang didaftar. Dengan diterbitkannya sertipikat, seseorang dengan mudah dapat membuktikan bahwa dirinya sebagai pemilik tanah atau pemegang hak atas tanah.

Sertipikat diterbitkan dengan maksud memberikan jaminan kepastian hukum dan perlindungan hukum bagi pemilik tanah atau pemegang hak atas tanah. Namun demikian, dalam realita ada pihak yang merasa dirugikan atas diterbitkannya sertipikat. Timbulnya kerugian ini disebabkan adanya penyimpangan dalam penerbitan sertipikat. Dari uraian pendahuluan ini dapat dirumuskan masalah yang hendak dikaji, yaitu mengapa penyimpangan dalam penerbitan sertipikat selalu terjadi sehingga menimbulkan kerugian bagi seseorang.

\section{PEMBAHASAN \\ Penerbitan dan Substansi Sertipikat Hak atas Tanah}

Kegiatan yang dilakukan oleh pemerintah secara terus-menerus, berkesinambungan dan juga teratur, meliputi pengumpulan, pengolahan, pembukuan, dan penyajian serta pemeliharaan akan data fisik dan juga data yuridis, dalam bentuk peta dan daftar, mengenai bidang-bidang tanah dan satuan-satuan rumah susun, termasuk pemberian surat tanda bukti 
haknya bagi bidang-bidang tanah yang sudah ada haknya dan hak milik atas satuan rumah susun serta hak-hak tertentu yang membebaninya sesuai dengan pendaftaran tanah yang diatur dalam Pasal 1 angka 1 Peraturan Pemerintah No. 24 Tahun 1997.

Berdasarkan pengertian pendaftaran tanah terdapat beberapa kegiatan antara lain: 1. Pendaftaran tanah diadakan oleh pemerintah; 2. Kegiatan pendaftaran tanah tidak sekali selesai melainkan terus-menerus, berkesinambungan, dan juga teratur; 3. Kegiatan pendaftaran tanah adalah pengumpulan, pengolahan, pembukuan, dan penyajian serta pemeliharaan data fisik dan data yuridis, dalam bentuk peta dan daftar; 4 . Objek pendaftaran tanah adalah bidang-bidang tanah dan satuan-satuan rumah susun; 5. Salah satu kegiatan dalam pendaftaran tanah adalah pemberian surat tanda bukti haknya bagi bidang-bidang tanah yang sudah ada haknya dan hak milik atas satuan rumah susun serta hak-hak tertentu yang membebaninya.

Sistem pendaftaran tanah yang mana dipergunakan oleh Peraturan Pemerintah No. 24 Tahun 1997 adalah sistem pendaftaran hak (registration of titles), bukan sistem pendaftaran akan akta (registration of deeds). Dalam sistem pendaftaran hak nampak dengan adanya buku tanah sebagai dokumen yang mana memuat data fisik dan data yuridis yang dihimpun dan disajikan serta diterbitkannya sertipikat sebagai surat tanda bukti hak yang telah didaftar (Boedi Harsono, 2003: 484). Dalam pendaftaran akta, yang didaftar bukan haknya, melainkan justru aktanya yang didaftar, yaitu dokumen-dokumen yang membuktikan diciptakannya hak yang bersangkutan dan dilakukan perbuatanperbuatan hukum mengenai hak tersebut kemudian (Boedi Harsono, 2003:74).

Tujuan pendaftaran tanah ditetapkan dalam Pasal 3 dan Pasal 4 Peraturan Pemerintah No. 24 Tahun 1997 sebagai berikut:

Pertama, Untuk memberikan kepastian hukum dan perlindungan hukum kepada pemegang hak atas suatu bidang tanah, satuan rumah susun dan hak-hak lain yang terdaftar agar dengan mudah dapat membuktikan dirinya sebagai pemegang hak yang bersangkutan. Untuk memberikan jaminan kepastian hukum dan perlindungan hukum dalam pendaftaran tanah, kepada pemegang hak yang bersangkutan diberikan sertipikat sebagai tanda bukti haknya;

Kedua, Untuk mengadakan informasi, kepada pihak-pihak yang mana berkepentingan termasuk Pemerintah agar dengan mudah dapat memperoleh data yang diperlukan dalam mengadakan perbuatan hukum mengenai bidang-bidang tanah dan satuansatuan rumah susun yang sudah terdaftar. Untuk melaksanakan fungsi informasi, data fisik dan data yuridis dari bidang tanah dan satuan rumah susun yang sudah terdaftar terbuka untuk umum;

Ketiga, Untuk terselenggaranya tertib administrasi pertanahan. Untuk mencapai tertibnya administrasi pertanahan, setiap bidang tanah dan satuan rumah susun termasuk peralihan, pembebanan, dan hapusnya hak atas bidang tanah dan hak milik atas satuan rumah susun wajib didaftar.

Pendaftaran tanah yang diadakan oleh pemerintah menurut Pasal 19 ayat 1 UUPA adalah pendaftaran tanah yang bertujuan memberikan jaminan kepastian hukum atau yang disebut rechts cadaster. Menurut Adrian Sutedi, pendaftaran akan tanah dalam rangka rechts cadaster bertujuan memberikan kepastian hukum dan perlindungan hukum kepada pemegang hak atas tanah, dengan alat bukti yang dihasilkan pada akhir proses pendaftaran tanah tersebut berupa buku tanah dan sertipikat yang terdiri dari salinan buku tanah dan surat ukur. Sertipikat hak atas tanah merupakan alat pembuktian yang kuat sebagaimana dinyatakan dalam Pasal 19 ayat 2 huruf c, Pasal 23 ayat 2, Pasal 32 ayat 2, dan Pasal 38 ayat 2 UUPA. Sertipikat hanya merupakan tanda bukti hak yang kuat dan bukan merupakan tanda bukti hak yang mutlak (Adrian Sutedi, 2007:112-113).

Pasal 19 ayat 1 UUPA, Pasal 1 angka 1 Peraturan Pemerintah No. 24 Tahun 1997 menetapkan bahwa pihak yang mengadakan pendaftaran tanah adalah pemerintah. Dalam hal ini yang dimaksud dengan pemerintah disini adalah Badan Pertanahan Nasional (yang selanjutnya disebut BPN) Republik Indonesia. Pendaftaran tanah itu diselenggarakan oleh BPN Republik Indonesia. Dalam rangka penyelenggaraan pendaftaran tanah, tugas pelaksanaan pendaftaran tanah itu dilakukan oleh Kepala Kantor Pertanahan Kabupaten atau juga Kota. Dalam kegiatan-kegiatan tertentu, Kepala Kantor Pertanahan Kabupaten/Kota akan dibantu oleh: 1. Pejabat Pembuat Akta Tanah; 2. Pejabat Pembuat Akta Ikrar Wakaf; 3. Panitia Ajudikasi; 4. Pejabat dari Kantor Lelang.

BPN dalam struktur organisasi dibagi menjadi 3 (tiga) berdasarkan wilayah administrasi sebagai berikut: Pertama, Di tingkat Pusat (Ibukota Republik Indonesia) dibentuklah BPN Republik Indonesia (BPNRI); Kedua, Di tingkat Propinsi dibentuklah Kantor Wilayah BPN Republik Indonesia (Kanwil BPN Propinsi); Ketiga, Di tingkat Kabupaten/Kota dibentuk Kantor Pertanahan Kabupaten/Kota (Kantah Kabupaten/Kota).

Bidang-bidang tanah dan satuan rumah susun yang menjadi obyek pendaftaran tanah, adalah: Bidang- 
bidang tanah yang dipunyai dengan Hak Milik, Hak Guna Usaha, Hak Guna Bangunan, dan Hak Pakai; Tanah Hak Pengelolaan; Tanah Wakaf; Hak Milik atas Satuan Rumah Susun; Hak Tanggungan; Tanah Negara.

Ada beberapa kegiatan dalam pendaftaran tanah, yang ditetapkan dalam Pasal 19 ayat 2 UUPA antara lain: 1. pengukuran, perpetaan, dan pembukuan tanah; 2. pendaftaran hak-hak atas tanah dan peralihan hakhak tersebut; 3 . pemberian surat-surat tanda bukti hak yang berlaku sebagai alat pembuktian yang kuat.

Kegiatan pendaftaran tanah dalam Pasal 19 ayat 2 UUPA dijabarkan oleh Pasal 11 dan Pasal 12 Peraturan Pemerintah No. 24 Tahun 1997, yaitu:

Pertama, yaitu kegiatan Pendaftaran Tanah untuk Pertamakalinya. Kegiatan pendaftaran tanah untuk pertamakali adalah kegiatan pendaftaran tanah yang dilakukan terhadap obyek pendaftaran tanah yang belum didaftar berdasarkan Peraturan Pemerintah No. 10 Tahun 1961 tentang Pendaftaran Tanah atau Peraturan Pemerintah No. 24 Tahun 1997 tentang Pendaftaran Tanah.

Kegiatan pendaftaran tanah untuk pertamakali dilakukan melalui pendaftaran tanah secara sistematik dan pendaftaran tanah secara sporadik. Pendaftaran tanah secara sistematik adalah kegiatan pendataran tanah pertamakali yang dilakukan secara serentak yang meliputi semua objek pendaftaran tanah yang belum didaftar dalam wilayah atau bagian wilayah suatu Desa/Kelurahan. Pendaftaran tanah sporadik adalah kegiatan pendaftaran tanah untuk pertamakali mengenai satu atau beberapa objek pendaftaran tanah dalam wilayah atau bagian wilayah suatu Desa/ Kelurahan secara individual atau massal.

Kegiatan pendaftaran tanah untuk pertamakali, meliputi: pengumpulan dan pengolahan data fisik; pembuktian hak dan juga pembukuannya; penerbitan sertipikat; penyajian data fisik dan juga data yuridis; penyimpanan daftar umum dan dokumen.

Kedua, Kegiatan Pemeliharaan Data Pendaftaran Tanah. Kegiatan akan pemeliharaan data pendaftaran tanah merupakan kegiatan pendaftaran tanah untuk menyesuaikan data fisik, dan data yuridis dalam peta pendaftaran, daftar tanah, daftar nama, surat ukur, buku tanah, dan sertipikat dengan perubahanperubahan yang terjadi kemudian.

Kegiatan pemeliharaan data pendaftaran tanah meliputi: 1. pendaftaran peralihan dan pembebanan hak; 2. pendaftaran perubahan data pendaftaran tanah lainnya.

Kegiatan pendaftaran tanah untuk pertamakali yang dilakukan melalui pendaftaran tanah secara sistematik dan pendaftaran tanah secara sporadik akan dapat menghasilkan surat tanda bukti hak yang mana diberi nama sertipikat. Menurut Pasal 1 angka 20 Peraturan Pemerintah No. 24 Tahun 1997, yang dimaksud sertipikat adalah surat tanda bukti hak sebagaimana dimaksud dalam Pasal 19 ayat 2 huruf c UUPA untuk hak atas tanah, hak pengelolaan, tanah wakaf, hak milik atas satuan rumah susun, dan hak tanggungan yang masing-masing sudah dibukukan dalam buku tanah yang bersangkutan. Berdasarkan obyek dari pendaftaran tanah, ada bermacam-macam sertipikat, yaitu meliputi: 1. Sertipikat Hak Milik; 2. Sertipikat Hak Guna Usaha; 3. Hak Guna Bangunan atas Tanah Negara; 4. Hak Guna Bangunan atas Tanah Hak Pengelolaan; 5. Sertipikat Hak Pakai atas Tanah Negara; 6. Sertipikat Hak Pakai atas suatu Tanah Hak Pengelolaan; 7. Sertipikat Tanah Wakaf; 8. Sertipikat Hak Pengelolaan; 9. Sertipikat Hak Milik atas Satuan Rumah Susun; 10. Sertipikat Hak Milik atas Satuan Non Rumah Susun; 11. Sertipikat Hak Tanggungan (Urip Santoso, 2010:261).

Sertipikat hak atas tanah diperoleh perseorangan atau badan hukum melalui 2 (dua) cara, yaitu:

Pertama, Penegasan Konversi. Pengertian dari konversi adalah perubahan status hak atas tanah dari hak atas tanah menurut hukum yang lama sebelum berlakunya UUPA menjadi hak atas tanah menurut UUPA.

Sertipikat hak atas tanah yang diperoleh melalui penegasan konversi, yaitu seseorang Warga Negara Indonesia yang mengajukan permohonan penegasan konversi dari hak atas tanah yang mana tunduk pada Hukum Adat atau tanah yasan yang bertanda bukti Petuk Pajak Bumi atau Landrente, Girik, Kekitir, Pipil, Verponding Indonesia, IPEDA, IREDA, atau Kutipan Letter C kepada Kepala Kantor Pertanahan Kabupaten/Kota.

Dari proses permohonan penegasan konversi ini diterbitkan Sertipikat Hak Milik oleh Kepala Kantor Pertanahan Kabupaten/Kota.

Kedua, Penetapan Pemerintah. Penetapan dari Pemerintah adalah keputusan yang diterbitkan oleh Kepala BPN Republik Indonesia atau pejabat BPN Republik Indonesia yang mana diberikan pelimpahan kewenangan dalam pemberian hak atas tanah.

Penetapan pemerintah akan diterbitkan karena permohonan pemberian hak atas tanah yang mana berasal dari tanah Negara oleh perseorangan atau badan hukum. Atas permohonan pemberian hak ini diterbitkan Surat Keputusan Pemberian Hak (yang selanjutnya disebut SKPH) oleh pihak Kepala BPN Republik Indonesia, atau pejabat dari BPN Republik 
Indonesia yang diberikan pelimpahan kewenangan dalam pemberian hak. Surat Keputusan Pemberian Hak ini merupakan suatu Penetapan Pemerintah. Hak penguasaan atas tanah yang diterbitkan dapat berupa Hak Milik, Hak Guna Usaha, Hak Guna Bangunan, Hak Pakai, dan Hak Pengelolaan. SKPH tersebut wajib didaftarkan oleh pemohon pemberian hak, kepada Kepala Kantor Pertanahan Kabupaten atau Kota yang wilayah kerjanya meliputi letak tanah yang bersangkutan untuk diterbitkan sertipikat hak.

Penetapan Pemerintah dapat diterbitkan karena permohonan pemberian akan Hak Guna Bangunan atau Hak Pakai atas tanah Hak Pengelolaan oleh perseorangan atau pun suatu badan hukum kepada Kepala Kantor Pertanahan Kabupaten atau Kota, yang wilayah kerjanya meliputi letak tanah yang bersangkutan. Atas permohonan pemberian hak ini diterbitkan Surat Keputusan Pemberian Hak oleh Kepala Kantor Pertanahan Kabupaten atau Kota, yang wilayah kerjanya meliputi letak tanah yang bersangkutan. Surat Keputusan Pemberian Hak ini merupakan Penetapan Pemerintah. SKPH tersebut wajib didaftarkan oleh pemohon pemberian hak, kepada Kepala Kantor Pertanahan Kabupaten atau Kota yang wilayah kerjanya meliputi letak tanah yang bersangkutan untuk diterbitkan sertipikat Hak Guna Bangunan, atau Hak Pakai atas tanah Hak Pengelolaan.

Sertipikat diterbitkan oleh Kantor Pertanahan Kabupaten atau Kota. Pejabat yang menandatangani sertipikat, antara lain: 1. Kepala Kantor Pertanahan Kabupaten/Kota dalam pendaftaran tanah secara sporadik yang bersifat individual; 2. Kepala Seksi Pengukuran dan juga Pendaftaran Tanah atas nama Kepala Kantor Pertanahan Kabupaten atau Kota, dalam pendaftaran tanah secara sporadik yang mana bersifat massal; 3. Ketua Panitia Ajudikasi atas nama Kepala Kantor Pertanahan Kabupaten atau Kota dalam pendaftaran tanah secara sistematik.

Sertipikat hak atas tanah berisi 2 (dua) macam data, data fisik dan data yuridis. Data fisik adalah keterangan mengenai letak, batas, dan luas tanah, dan satuan rumah susun yang didaftar, termasuk keterangan mengenai adanya bangunan atau bagian bangunan diatasnya. Data yuridis adalah keterangan mengenai status hukum bidang tanah dan satuan rumah susun yang didaftar, pemegang hak dan pihak lain serta beban-beban lain yang membebaninya. Essensi sertipikat hak atas tanah adalah surat bukti hak atas bidang tanah yang berisi salinan buku tanah yang memuat data fisik dan data yuridis, dan surat ukur yang memuat data fisik. Maksud diterbitkan sertipikat adalah pemegang hak dengan mudah dapat membuktikan bahwa dirinya itu sebagai pemegang haknya, memberikan jaminan akan kepastian hukum dan perlindungan hukum bagi pemilik sertipikat. Sertipikat diterbitkan untuk kepentingan pemegang hak yang bersangkutan sesuai dengan data fisik dan data yuridis yang telah didaftar dalam buku tanah. Sertipikat hanyalah boleh diserahkan kepada pihak yang namanya tercantum dalam buku tanah yang bersangkutan sebagai pemegang hak atau kepada pihak lain yang dikuasakan olehnya.

Dengan diterbitkan sertipikat hak atas tanah, maka terwujud jaminan kepastian hukum. Ruang lingkup jaminan kepastian hukum itu, meliputi: Pertama, Kepastian status hak atas tanah. Dengan pendaftaran tanah dapat diketahui dengan pasti status tanah yang didaftar, yaitu Hak Milik, Hak Guna Usaha, Hak Guna Bangunan, Hak Pakai, ataukah Hak Pengelolaan. Kedua, Kepastian subjek hak atas tanah. Dengan pendaftaran tanah dapat diketahui dengan pasti siapa subyek hak atas tanah, yaitu perseorangan ataukah badan hukum. Ketiga, Kepastian objek hak atas tanah. Dengan pendaftaran tanah dapat diketahui dengan pasti letak tanah yang didaftar, batas-batas tanah yang didaftar, dan luas tanah yang didaftar.

Mhd. Yamin Lubis dan juga Abd. Rahim Lubis menyatakan bahwasanya sertipikat berfungsi sebagai alat bukti hak, yang mana menyatakan tanah itu telah di administrasi oleh negara. Lalu diberikan buktinya kepada orang yang mengadministrasi tanah tersebut. Sertipikat menjadi milik seseorang yang namanya tertera dalam sertipikat. Bagi pemilik tanah, sertipikat merupakan pegangan yang kuat dalam hal pembuktian hak miliknya, sebab sertipikat diterbitkan oleh instansi yang sah dan juga berwenang secara hukum. Hukum melindungi pemegang hak sertipikat tersebut dan lebih kokoh bila pemegangnya itu adalah namanya yang tersebut dalam sertipikat (Mhd. Yamin Lubis dan Abd. Rahim Lubis, 2008:204). Adrian Sutedi menjabarkan fungsi sertipikat hak atas tanah sebagai tanda bukti hak, yaitu (Adrian Sutedi, 2011:57-58): 1. Sertipikat hak atas tanah sebagai alat pembuktian yang kuat; 2 . Sertipikat hak atas tanah memberikan kepercayaan bagi pihak bank atau kreditor untuk memberikan pinjaman uang kepada pemiliknya; 3 . Bagi Pemerintah, adanya sertifikat hak atas tanah juga sangat menguntungkan walaupun kegunaan itu kebanyakan tidak langsung.

Dalam Pasal 19 ayat 2 huruf c UUPA menetapkan bahwa salah satu kegiatan pendaftaran tanah adalah pemberian surat-surat tanda bukti hak yang berlaku sebagai alat pembuktian yang kuat. Pasal 23, Pasal 32, 
dan Pasal 38 UUPA menetapkan bahwa pendaftaran Hak Milik, Hak Guna Usaha dan Hak Guna Bangunan merupakan alat pembuktian yang kuat. Pasal 19 ayat 2 huruf c, Pasal 23, Pasal 32, dan Pasal 38 UUPA tidak memberikan pengertian apa yang dimaksud alat pembuktian yang kuat. Surat tanda bukti hak yang berlaku sebagai alat pembuktian yang kuat dijabarkan dalam Pasal 32 ayat 1 Peraturan Pemerintah No. 24 Tahun 1997, yaitu sertipikat merupakan surat tanda bukti hak, yang berlaku sebagai alat pembuktian yang kuat mengenai data fisik dan data yuridis yang termuat dalamnya, sepanjang data fisik dan data yuridis tersebut sesuai dengan data yang ada dalam surat ukur dan buku tanah yang bersangkutan.

Dalam rangka memberikan jaminan kepastian hukum kepada pemegang hak atas tanah dan agar dengan mudah dapat membuktikan dirinya sebagai pemegang hak yang bersangkutan, maka di dalam Penjelasan Pasal 32 ayat 1 Peraturan Pemerintah No. 24 Tahun 1997 diberikan penjelasan resmi mengenai arti alat pembuktian yang kuat, bahwa sertipikat merupakan tanda bukti hak yang kuat, dalam arti selama tidak dapat dibuktikan sebaliknya data fisik dan data yuridis yang tercantum dalam sertipikat harus sesuai dengan data yang tercantum dalam buku tanah dan surat ukur yang bersangkutan, karena data itu diambil dari buku tanah dan surat ukur tersebut.

Sehubungan dengan sertipikat sebagai tanda bukti hak yang bersifat kuat, Boedi Harsono menyatakan bahwa selama tidak dapat dibuktikan sebaliknya, data fisik dan data yuridis yang tercantum di dalamnya harus diterima sebagai data yang benar, baik dalam melakukan perbuatan hukum sehari-hari maupun dalam perkara di pengadilan. Sudah barang tentu data fisik dan data yuridis yang tercantum dalam sertipikat harus sesuai dengan data yang tercantum dalam surat ukur dan buku tanah yang bersangkutan, karena data itu diambil dari surat ukur dan buku tanah tersebut (Boedi Harsono, 2003:480). Sejalan dengan yang dikemukakan oleh Boedi Harsono, Arie S. Hutagalung (Arie S. Hutagalung, 2005:81-82) menyatakan bahwa sertipikat hanya merupakan tanda bukti yang kuat dan bukan merupakan tanda bukti yang mutlak atau sempurna menurut ketentuan UUPA dan Peraturan Pemerintah yang melaksanakannya (PP No. 10 Tahun 1961 dan PP No. 24 Tahun 1997). Keterangan yang tercantum didalamnya mempunyai kekuatan hukum dan harus diterima (oleh hakim) sebagai keterangan yang benar dan sepanjang tidak ada alat pembuktian yang membuktikan sebaliknya. Pengadilanlah yang akan memutuskan alat pembuktian mana yang benar dan apabila ternyata data dari pendaftaran tanah tidak benar, maka diadakan perubahan dan pembetulan atas keputusan pengadilan tersebut.

Sertipikat sebagai tanda bukti hak yang bersifat kuat mengandung pengertian bahwa data fisik dan data yuridis yang dimuat dalam sertipikat mempunyai kekuatan bukti dan harus diterima sebagai keterangan yang benar selama tidak dibuktikan sebaliknya dengan alat bukti yang lain, yang bisa berupa sertipikat atau petuk pajak bumi atau kutipan Letter C. Kalau dalam satu bidang tanah terdapat 2 (dua) tanda bukti hak berupa satu sertipikat dan satunya petuk pajak bumi atau kutipan Letter $C$, dan disengketakan oleh para pihak, maka pengadilanlah yang akan memutuskan tanda bukti hak mana yang benar. Kalau ternyata bahwa data fisik dan juga data yuridis yang dimuat dalam sertipikat tidak benar, maka akan diadakan pembetulan sebagaimana mestinya.

Berkaitan dengan sertipikat sebagai tanda bukti hak yang bersifat kuat, sertipikat yang diterbitkan oleh Kantor Pertanahan Kabupaten atau Kota masih dapat diganggu gugat oleh pihak lain yang merasa dirugikan atas diterbitkannya sertipikat. Gugatan tersebut diajukan diajukan ke Pengadilan Negeri kalau sengketanya perdata, sedangkan gugatan diajukan ke Pengadilan Tata Usaha Negara kalau sengketanya tata usaha negara. Putusan Pengadilan Negeri memutuskan bahwa pemilikan ataupun penguasaan tanah oleh seseorang atau badan hukum tidak benar, sedangkan putusan Pengadilan Tata Usaha Negara memutuskan bahwa sertipikat tidak sah atau batal.

Meskipun sudah diterbitkan sertipikat hak atas tanah tetapi belum memberikan rasa aman dan tenang kepada pemilik sertipikat, karena disebabkan sewaktuwaktu pemilik digugat oleh pihak lain yang merasa dirugikan atas diterbitkannya sertipikat itu. Dengan kata lain, pemilik sertipikat itu belum mendapatkan perlindungan hukum yang sepenuhnya atas sertipikat yang dimilikinya karena sewaktu-waktu mendapatkan gugatan daripada pihak lain. Dengan diterbitkannya sertipikat, pemegang hak atas tanah dengan mudah dapat membuktikan bahwa dirinya sebagai pemilik atau pemegang hak atas tanah. Namun demikian, berdasarkan ketentuan Pasal 32 ayat 1 Peraturan Pemerintah No. 24 Tahun 1997 tidak ada jaminan bagi pemilik tanah atau pemegang hak atas tanah tidak mendapatkan gugatan dari pihak lain yang merasa dirugikan atas telah diterbitkannya sertipikat tersebut. Demikian pula, BPN Republik Indonesia tidak menjamin kebenaran data fisik dan data yuridis yang dimuat dalam sertipikat.

Kegiatan pendaftaran tanah untuk pertamakali sebagai suatu proses yang mana diakhiri dengan 
diterbitkannya sertipikat oleh Kantor Pertanahan Kabupaten atau Kota, mempunyai manfaat yang dapat diperoleh oleh 3 (tiga) pihak, yaitu: Pertama, Pemegang hak atas tanah: 1 . Dengan mudah dapat membuktikan bahwasanya dirinya sebagai pemegang hak atas tanah; 2. Memperoleh jaminan kepastian hukum dan perlindungan hukum; 3. Memudahkan dalam pelaksanaan peralihan hak atas tanah; 4. Harga tanah menjadi lebih mahal bila dibandingkan dengan tanah, yang tidak bersertipikat; 5. Bila dijadikan jaminan utang nilainya lebih tinggi daripada tidak bersertipikat; 6. Penetapan Pajak Bumi dan Bangunan tidak mudah keliru. Kedua, Pemerintah: 1. Dapat tercipta tertibnya administrasi pertanahan; 2. Dapat memperlancar dalam kegiatan pemerintahan yang berkaitan dengan tanah dalam hal pembangunan; 3 . Dapat mengurangi sengketa di bidang pertanahan. Ketiga, Calon pembeli atau juga calon kreditor. Bagi calon pembeli atau calon kreditor dapat memperoleh keterangan yang jelas dan pasti mengenai data fisik dan juga data yuridis tanah yang akan menjadi objek perbuatan hukum.

Manfaat yang mana dapatlah diperoleh dengan diterbitkannya sertipikat dikemukakan oleh Maria S.W. Sumardjono yaitu sertipikat yang memberikan manfaat, misalnya saja dapat mengurangi timbulnya sengketa dengan pihak lain, memperkuat posisi tawar menawar apabila hak atas tanah diperlukan oleh pihak lain, untuk kegiatan pembangunan, mempersingkat proses peralihan hak atas tanah, dan pembebanan hak atas tanah. Bagi pemegang hak atas tanah, memiliki sertipikat mempunyai nilai lebih. Sebab, dibandingkan dengan alat bukti tertulis lain, sertipikat merupakan tanda bukti tanda bukti hak yang kuat, artinya harus dianggap sebagai benar sampai dibuktikan sebaliknya di pengadilan (Maria S.W. Sumardjono, 2005:202).

\section{Bentuk Penyimpangan dalam Hal Penerbitan Sertipikat Hak atas Tanah}

Dalam praktek terdapat penyimpangan dalam penerbitan sertipikat hak atas tanah, antara lain:

Pertama, Sertipikat Palsu. Ketentuan-ketentuan yang ada di dalam sertipikat palsu antara lain: 1 . Sebidang tanah diterbitkan sertipikat tanah yang berstatus Hak Milik, Hak Guna Usaha, Hak Guna Bangunan, Hak Pakai, atau Hak Pengelolaan; 2. Buku sertipikat hak atas tanah tidak diterbitkan oleh BPN Republik Indonesia; 3. Data fisik dan data yuridis tanah yang didaftar bisa benar atau salah; 4. Tanda tangan pejabat yang berwenang menandatangani sertipikat dipalsu; 5. Stempel Kantor Pertanahan Kabupaten atau Kota yang menerbitkan sertipikat dipalsu; 6. Petugas yang mengisi data fisik dan data yuridis dalam sertipikat bisa petugas yang berwenang atau petugas yang tidak berwenang.

Kedua, Sertipikat asli namun palsu. Ketentuanketentuan yang ada dalam sertipikat asli tapi palsu antara lain: 1. Sebidang tanah diterbitkan sertipikat yang berstatus Hak Milik, Hak Guna Usaha, atau Hak Guna Bangunan, Hak Pakai, atau Hak Pengelolaan; 2. Buku sertipikat diterbitkan oleh BPN Republik Indonesia (BPNRI); 3. Data fisik dan yuridis tanah yang didaftar bisa benar atau salah; 4. Tandatangan pejabat yang berwenang menandatangani sertipikat dipalsu; 5. Stempel Kantor Pertanahan Kabupaten atau Kota yang menerbitkan sertipikat dipalsu; 6 . Petugas yang mengisi data fisik dan data yuridis dalam sertipikat bisa petugas yang berwenang atau petugas yang tidak berwenang.

Ketiga, Sertipikat ganda. Ketentuan-ketentuan yang ada di dalam sertipikat ganda antara lain: 1. Sebidang tanah diterbitkan lebih dari satu sertipikat hak atas tanah; 2. Kedua atau lebih dari dua sertipikat bisa sama status hak atas tanah, atau bisa berbeda status hak atas tanahnya; 3 . Subjek hak atas tanah bisa sama-sama perseorangan, sama-sama badan hukum, atau perseorangan dan badan hukum; 4. Sertipikat hak atas tanah yang diterbitkan bisa sama-sama asli, sama-sama palsu, sama-sama asli tapi palsu, yang satu asli dan yang satu palsu, yang satu asli dan yang satu sali tapi palsu.

Keempat, Sertipikat tumpang tindih. Ketentuanketentuan dalam sertipikat tumpang tindih antara lain: 1. Sebidang tanah diterbitkan lebih dari satu surat tanda bukti hak; 2. Sertipikat hak atas tanah yang mana sebagian objeknya mengambil tanah milik atau pihak lain; 3. Kedua bidang tanah tersebut bisa sama status hak atas tanahnya atau berbeda status hak atas tanahnya; 4 . Kedua bidang tanah tersebut bisa sama-sama telah bersertipikat, atau yang satu telah bersertipikat dan yang satu belum bersertipikat; 5 . Sertipikat yang diterbitkan bisa asli, palsu, atau asli tapi palsu.

Kelima, Sertipikat fiktif. Ketentuan-ketentuan yang ada di dalam sertipikat fiktif antara lain: 1 . Sebidang tanah diterbitkan sertipikat hak atas tanah yang statusnya Hak Milik, Hak Guna Usaha, Hak Guna Bangunan, Hak Pakai, atau Hak Pengelolaan; 2. Subjek hak atas tanah berupa perseorangan atau badan hukum; 3. Sertipikat hak atas tanah bisa asli, atau palsu; 4. Tidak ada data fisiknya (objeknya tidak ada); 5. Data fisik dan data yuridis diisi oleh petugas yang berwenang dari BPN Republik Indonesia, atau diisi oleh orang yang tidak berwenang; 6 . Tandatangan 
Kepala Kantor Pertanahan Kabupaten atau Kota yang berwenang menandatangani bisa asli atau dipalsu tandatangannya; 7. Stempel dari Kantor Pertanahan Kabupaten atau Kota bisa asli atau dipalsu.

\section{PENUTUP}

\section{Kesimpulan}

Pendaftaran tanah yang mana diselenggarakan oleh BPN Republik Indonesia. dalam pelaksanaannya dilakukan oleh Kepala Kantor Pertanahan Kabupaten atau Kota. Kegiatan pendaftaran tanah untuk pertamakali menghasilkan surat tanda bukti hak, yang berupa sertipikat hak atas tanah.

Sertipikat hak atas tanah berisi salinan dari buku tanah yang berisi data fisik dan data yuridis, dan surat ukur yang berisi data fisik. Dengan diterbitkannya sertipikat hak atas tanah, maka terwujud jaminan kepastian hukum dan juga perlindungan hukum bagi pemilik sertipikat. Dengan diterbitkannya sertipikat hak atas tanah, maka seseorang atau badan hukum dengan mudah dapat membuktikan bahwa dirinya sebagai pemilik atau pemegang hak atas tanah.

Sertipikat hak atas tanah itu sebagai surat tanda bukti hak yang bersifat kuat, artinya data fisik dan data yuridis yang tercantum dalam sertipikat harus dinyatakan sebagai data yang benar sepanjang tidak dibuktikan sebaliknya dengan surat tanda bukti yang lain. Sertipikat hak atas tanah yang diterbitkan oleh Kantor Pertanahan Kabupaten atau Kota masih dapat digugat oleh pihak lain yang merasa dirugikan atas diterbitkannya sertipikat hak atas tanah ke Pengadilan Negeri kalau sengketanya perdata, atau ke Pengadilan Tata Usaha Negara kalau sengketanya tata usaha negara.

Bentuk penyimpangan dalam penerbitan sertipikat hak atas tanah dapat berupa sertipikat palsu, sertipikat asli tapi, sertipikat ganda, sertipikat tumpang tindih, dan sertipikat fiktif.

\section{Rekomendasi}

Untuk meminimalkan penyimpangan agar tidak terjadi penyimpangan dalam penerbitan sertipikat hak atas tanah yang berupa sertipikat palsu, sertipikat asli tapi palsu, sertipikat ganda, sertipikat tumpang tindih atau pun sertipikat fiktif, maka pemerintah dalam hal ini BPN atau Kepala Kantor Pertanahan Kota atau Kabupaten harus lebih jeli lagi dalam melihat dan meneliti asal-usul tanah tersebut sebelum mengeluarkan surat tanda bukti hak berupa sertipikat hak atas tanah.

\section{DAFTAR PUSTAKA}

\section{Buku:}

Harsono, Boedi, 2003, Hukum Agraria Indonesia Sejarah Pembentukan Undang-Undang Pokok Agraria, Isi, dan Pelaksanaannya, Jakarta: Djambatan.

Hutagalung, Arie S., 2005, Tebaran Pemikiran Seputar Masalah Hukum Tanah, Jakarta: Lembaga Pemberdayaan Hukum Indonesia.

Lubis, Mhd. Yamin dan Abd. Rahim Lubis, 2008, Hukum Pendaftaran Tanah, Bandung: Mandar Maju.

Santoso, Urip, 2010, Pendaftaran dan Peralihan Hak atas Tanah, Jakarta: Prenada Media.

Sumardjono, Maria S.W., 2005, Kebijakan Pertanahan antara Regulasi dan Implementasi, Jakarta: Penerbit Buku Kompas.

Sutedi, Adrian, 2007, Peralihan Hak atas Tanah dan Pendaftarannya, Jakarta: Sinar Grafika. , 2011, Sertifikat Hak atas Tanah, Jakarta: Sinar Grafika.

\section{Peraturan Perundang-undangan:}

Undang-Undang No. 5 Tahun 1960 tentang Peraturan Dasar Pokok-pokok Agraria.

Peraturan Pemerintah No. 10 Tahun 1961 tentang Pendaftaran Tanah.

Peraturan Pemerintah No. 24 Tahun 1997 tentang Pendaftaran Tanah.

Peraturan Menteri Negara Agraria/Kepala Badan Pertanahan Nasional No. 3 Tahun 1997 tentang Ketentuan Pelaksanaan Peraturan Pemerintah No. 24 Tahun 1997 tentang Pendaftaran Tanah. 